\title{
Pathways to Political Activism among Americans who have Same-Sex Sexual Contact
}

\author{
Eric Swank • Breanne Fahs
}

Published online: 8 February 2011

(C) Springer Science+Business Media, LLC 2011

\begin{abstract}
Empirical systematic studies on political activism among self-identified sexual minorities are sparse and underdeveloped. When using three waves of a random national survey of respondents who have sex with people of the same sex $(N=184)$, this study tested the predictive capabilities of "resource," "framing," and "network" theories of political participation. After running discriminant analysis regressions for electoral and protest activities, the potency of eclectic and integrative models became apparent. With many resource, framing, and network variables reaching statistical significance, the results suggest that activism is partly contingent upon changing political environments and the educational attainment of the respondents, as well as their interpretations of heterosexism, authoritarian principles, the collective efficacy of citizens, the number of civic groups they joined, and the embracing of activist precepts as their own.
\end{abstract}

Keywords Activism - Collective behavior.

Homosexuality · Gay rights · Lesbian rights · Political participation $\cdot$ Social movements $\cdot$ Social identity

Considering the lengthy existence of activism among sexual minorities, there are surprisingly few studies of what inspires such behaviors. Additionally, the rare empirical studies on activism among self-identified gays, lesbians,

\section{E. Swank $(\bowtie)$}

Department of Sociology, Social Work and Criminology,

Morehead State University,

Morehead, KY, USA

e-mail: e.swank@moreheadstate.edu

B. Fahs

Women and Gender Studies Program, Arizona State University, 4701 W. Thunderbird Road, Glendale, AZ 85302, USA

e-mail: breanne.fahs@asu.edu and bisexuals (GLB) have some noticeable shortcomings. These studies have been hurt by a small set of predictor variables or weaker sampling techniques. For example, most published accounts lack a comparison group of the politically disengaged since they relied upon snowball samples of activists (Jones 2002; Tester 2004; Waldner 2001), mailed surveys to members of gay and lesbian organizations (Rollins and Hirsch 2003; Simon et al. 1998; Sturmer and Simon 2004), or distributed surveys at political events (Elbaz 1996; Lombardi 1999; Waldner 2001).

This study extends earlier studies on $\mathrm{GLB}^{1}$ political participation in two major ways. First, we provide a broader range of independent variables, with the hopes that the synthesis of studies from Sociology, Psychology, and Political Science will capture most of the pertinent factors that motivate political activism among GLB citizens. Second, our use of a national random sample captures greater variance in political behaviors and enhances the representativeness of this study.

Sexual minorities can work for social change in many forms (Rimmerman 2007). Among other things, gays and lesbians can try to change the opinions of their fellow citizens, create and run voluntary associations, and try to improve governmental laws and regulations. The "statecentered" approach pushes for the creation or modification of important laws and statutes and/or the expansion of important governmental programs. By focusing on matters of policy formation, sexual minorities can use the conventional "insider" tactics of voting, lobbying, and campaign contributions along with the less conventional "outsider" tactics of community organizing, boycotting, and protest-

\footnotetext{
${ }^{1}$ Throughout the rest of this paper we sometimes use the terms gay, lesbian, and bisexual for people who have had "sexual experiences with people of the same sex." While we realize that some people who do such actions would not consider themselves anything but heterosexual, a large number of these individuals will.
} 
ing. By focusing on political participation among people who have same-sex sexual partners, these last options of doing "insider" and "outsider" tactics is what interests us most in this paper.

By looking at the political engagement of US citizens, this study centers on the factors that promote or hinder greater levels of political activism. Accordingly, we ask the research questions: first, what inspires greater or lesser amounts of political activism among Americans who have same-sex sexual experiences? Second, do the independent variables display similar predictive capabilities when analyzing "insider" and "outsider" political behaviors? We draw upon two literatures in order to see what differentiates the politically active from the politically inactive. Because this study explored activism on the behalf of any political cause, not specifically gay and lesbian rights, we initially employed a classical political science model of political participation (Brady et al. 1995; Leighley and Vedlitz 1999). Later we drew upon interdisciplinary studies on participation in the gay and lesbian rights movements since we believed that a good deal of our respondent's activism would focus on such matters (Jennings and Andersen 2003; Rollins and Hirsch 2003; Sturmer and Simon 2004; Taylor et al. 2009; Waldner 2001).

\section{Literature Review}

When choosing our predictor variables, we began with the "resource-model" of political participation (Brady et al. 1995). Offering a succinct answer to why people refrain from politics, the resource model asserts: "because they can't, because they don't want to, or because nobody asked" (Brady et al. 1995, p. 271). With regard to "they can't," many people refrain from politics because of a dearth of necessary resources to be political. While crucial resources may come in many forms, we emphasize the importance of obstacles that relate to financial constraints, leisure time, and civic skills. The concept of "they don't want to," deals with a lack of psychological engagement in politics. This indifference to politics is sometimes seen as political ignorance but the resource model assumes that this is a reaction to a lower sense of political efficacy and greater levels of individualism. For this study, politics lack salience to gays and lesbians when they think that politicians ignore GLB communities or when gay and lesbian individuals do not think they share a common destiny with people in their other social groups (e.g., race, gender, sexual identity). Finally, the "nobody asked" factor implies that people are isolated from the recruitment networks that move citizens into action. That is, people are less likely to be political if they rest outside of the social contexts that offer incentives and information about activism.
"They Can't": The Role of Income, Education and Status Hierarchies

Every society seems to have an unequal distribution of wealth, prestige and power. This unequal allocation of resources creates aggregates of people - social classeswho share similar amounts of income and life opportunities. The resource model assumes these class and status hierarchies are fundamental to political inclinations and activism (Brady et al. 1995). According to these authors, socioeconomic standing is a crucial variable that drives political participation for members of every social group in society (i.e., SES works across race, gender, religious or sexual orientation boundaries). In the simplest of terms, a person's class location supposedly grants or impedes access to opportunities and financial resources that make political activism easier. Subsequently, people in higher socioeconomic levels amass and retain the structural elicitors of activism, be it more money, wider educational opportunities, greater amounts of free time, or more chances to lead people in day-to-day scenarios.

Studies of the general population have found that greater affluence is linked to greater political engagement (Brady et al. 1995; Huddy and Khatib 2007; Leighley and Vedlitz 1999; Lim 2008: Tate 1991). However, these results are less consistent in studies of GLB activism. One study found that transsexuals who were employed in professional occupations were more involved in political campaigns than their blue-collar counterparts (Lombardi 1999). Other studies suggested that higher-income gays and lesbians belong to more gay organizations (Barrett and Pollack 2005) and attended more demonstrations for the recognition of samesex marriages (Taylor et al. 2009) and for more funding for AIDS programs (Jennings and Andersen 2003). Conversely, several studies argued that income did not predict the amount of involvement in gay and AIDS rights groups (Elbaz 1996; Sturmer and Simon 2004). Finally, one study found that poorer gays and lesbians routinely joined Queer Nation and ACT UP (Rollins and Hirsch 2003).

Although numerous studies find a link between education and political participation (Duncan 1999; Brady et al. 1995; Jasper and Poulsen 1995; La Due Lake and Huckfeldt 1998; Leighley and Nagler 1992) the role of education is less certain in studies of gay and lesbian activists. Two studies suggest ACT UP members were highly educated (Elbaz 1996; Rollins and Hirsch 2003) while four studies claim that educational attainment does differentiate the amount of political activism among gays and lesbians (Barrett and Pollack 2005; Lombardi 1999; Sturmer and Simon 2004; Waldner 2001).

The role of gender hierarchies and political participation is far from certain. Older studies suggested that heterosexual women, from the beginning of enfranchisement to the 1950s, have been slightly less inclined to be politically 
active (Arneson and Eells 1950). Conversely, newer studies suggest that this gender gap disappeared or has even reversed in the years that followed the second wave of the women's movement (Huddy and Khatib 2007; Lieghley and Nagler 1992; Tate 1991).

The lack of gender effects is mostly echoed in the studies of gay and lesbian political engagement. Several studies have suggested that the frequency of political activism was roughly the same with gays and lesbians (Jennings and Andersen 2003; Rollins and Hirsch 2003; Taylor et al. 2009; Waldner 2001) while one study argued that males significantly outnumbered females in ACT UP New York (Elbaz 1996).

\section{“They Don’t Want To": Framing Grievances, Efficacy, and Collective Identities}

Frames are generally conceived as cultural tools or schemas that provide "tacit theories about what exists, what happens, and what matters" (Gitlin 1980, p. 6). While conservative frames prioritize deference to conventional standards, collective action frames do the exact opposite: they motivate people into joining collective efforts that publicly seek social change. Or, in the words of William Gamson (1992), "Collective action frames are 'sets of action oriented beliefs and meanings that inspire and legitimate [collective action]"” (p. 7).

Movement theorists have identified several dimensions of collective action frames (Gamson 1992; Klandermans 1996; Taylor and Whittier 1992). First, collective action frames initially render some societal norms as wrong, unacceptable, and unjust. In naming the injustice, Snow and Benford (1992) suggested these frames serve as "accenting devices that either underscore or embellish the seriousness and injustice of a social condition or redefines it as unjust immoral" (p. 137). These injustice frames can highlight many sorts of maltreatments but they often generate greater salience when they focus on violations of fairness or equity norms. Second, frames identify the causes of the injustice. By providing a diagnostic function, frames are etiologies that explain why problems exist and assign levels of blame or capability to different entities. To make these attributions, frames highlight the sorts of practices that should be modified, transformed, or eliminated. Third, frames also convince bystanders that they should use political tactics to stop these violations. These prognostic aspects of frames usually emphasize the urgency of political action and a sense that challenges from less powerful constituencies can force concessions from a reluctant target; this confidence in movement tactics is sometimes called "agency" or a "sense of collective efficacy." In short, collective action frames must assure gays and lesbians that electoral or protest movements are an appropriate and viable response to their grievances. Finally, frames must provide a collective or shared identity among the aggrieved. In doing so, collective identities establish social boundaries of "us" and "them" by specifying who belongs to the righteous in-group of the mistreated and who exemplifies the antagonistic wrongdoers who must be challenged. These collective identities often contest and refute societal claims that members of their group are inferior, worthless, sick or maladjusted. Instead, collective action frames offer narratives about the virtues of similar people and that their group is illegitimately threatened, deprived, or treated badly. These collective identities enhance a sense of solidarity and loyalty for the people who share the same problems and some distrust or contempt for the people or institutions that maintain these problems. It is the goal of this paper to ascertain the sort of injustice, attributional, prognostic, and collective identity frames that precede electoral efforts at social change.

In an interesting development, explanatory studies of gay and lesbian activism have mostly failed to incorporate issues of perceived societal injustices into their models. To date, only Simon et al. (1998) has shown that gays activist in Germany are more like to criticize marriage laws as discriminatory marriage than their politically disinterested counterparts. This means that perceptions of discrimination and "modern heterosexism" are woefully understudied, as is the role of accepting hostile, covert, and blatant side heterosexism that "denies, denigrates, and stigmatizes any nonheterosexual form of behavior, identity, relationship, or community" (Herek 1992, p. 89). This omission of measures on acceptance of "old-style" heterosexism is a glaring problem since earlier studies have found that stigmatized populations who internalize negative stereotypes about women or racial minorities are less likely to be feminist or civil rights activists (Cole et al. 1998; Lien 1993; Miller et al. 1981; Stokes 2003). Moreover, some early studies have noticed that both conservative and liberal heterosexuals were more likely to vote in the 2004 elections when they had strong opinions about gay marriages (Sitka and Bauman 2008).

Issues of concealing one's identity and "passing-asstraight" are inevitably linked to gay and lesbian rights activism. To a movement that tries to "gain the recognition for new social identities," the very act of being out challenges the veracity of compulsorily heterosexuality (Bailey 1999; Bernstein 1997; Taylor and Whittier 1992). The revealing of GLB identities breaks the veil of silence and disrupts the myth that every human is exclusively heterosexual. The public assertion of a gay or lesbian identity in turn implies that the actor has in some way broken from essential assumptions of internalized heteronormativity. That is, a gay identity can be embraced and need not always be rejected, denied, or repudiated. Finally, the actor realizes that his or her disclosure could net hostile 
responses but he or she is willing to do so anyway. This suggests that deference to heterosexist rules cannot be guaranteed and heterosexuals must recognize the presence of GLB populations and their needs.

For the sake of our dependent variable, it also is clear that identities can be tools of political empowerment. Conversely, a study of college students revealed that lesbians were more inclined to assertively challenge homophobic comments when they embraced the activists norms of "standing up for what's right" and defending the rights of subordinated groups (Hyers 2007). When addressing activist inclinations, studies have found that gays and lesbians were more interested in political activism after they fully committed to their sexual identity (Konik and Stewart 2004) or felt solidarity with other sexual minorities (Friedman and Leaper 2010). In light of political behaviors, Rollins and Hirsch (2003) found that people who called themselves "queer" were more likely to join AIDS advocacy groups while Waldner (2001) discovered greater political involvement when gays and lesbians were unwilling to hide their sexual identity (see also Gortmaker and Brown 2006). However, one study warns that the significant relationship between joining a gay rights demonstration and disguising a gay orientation disappeared when they moved from a bivariate to multivariate analysis (Simon et al. 1998).

It is argued that gays and lesbians often become aware of heterosexism by observing or hearing about the mistreatment of other GLB people (Evans and Herriott 2004; Hartman 2005). Additionally, surviving first-hand discrimination seems especially salient to gay and lesbian activism. The circumscribed, face-to-face nature of experienced discrimination makes it more proximal and salient than institutionalized forms of biases. This immediacy may create pressing impulses to challenge this hardship, yet this impulse may be curbed or suppressed since heterosexism insists that GLBs should be passive, accommodating, silent, or self-hating. This combination of suppression and discrimination can foster a number of detrimental coping mechanisms such as disengagement (Edwards and Romero 2008), withdrawal or avoidance (Thompson 2006), and tendencies toward stigmatizing others (Swim and Thomas 2006).

Although surviving discrimination can lead to negative consequences, cases of first-hand discrimination seem equally important to gay and lesbian activism (Friedman and Leaper 2010; Jennings and Andersen 2003; Hyers 2007; Taylor et al. 2009; Waldner 2001). Two studies on AIDS activism found that gay men were more likely to protest governmental policies when they were demeaned by the medical professionals (Jennings and Andersen 2003; Tester 2004). Other studies have found that gays and lesbians who dealt with sexual and verbal harassment, or discrimination in housing and employment, were more likely to join radical gay rights groups (Rollins and Hirsch 2003; Simon et al. 1998; Waldner 2001).

Some of the participation studies suggest that efficacy perceptions are related to the protesting inclinations of gays and lesbians (Jennings and Andersen 2003; Jones 2002). For example, Jennings and Andersen (2003) suggested that gay men were more likely to join AIDS advocacy groups when they thought they had a good understanding of political issues. However, one study found that perceptions of political efficacy was irrelevant to how often married gays and lesbians joined gay right groups or attended a political demonstration (Taylor et al. 2009) and the only quantitative study of gay and lesbian electoral activism noted that "power expectancies" worked in the exact opposite ways as predicted (Waldner 2001). That is, homosexuals were more likely to join a gay-lesbian political campaign when they thought the government was unresponsive to gay or lesbian demands.

\section{"Nobody Asked": Membership in Civic Associations} and Recruitment Networks

Theories about "mobilizing structures" suggest that residing in certain social environments fosters greater political activism (Cole et al. 1998; McAdam and Paulsen 1993; McCarthy 1996; Passy 2001; Polleta and Jasper 2001). Social networks, which represent webs of recurring interactions between people and groups, always conveys some sort of beliefs, values, norms and identities. Most people derive their worldviews and identities through institutions and networks that praise the righteousness of prevailing social orders and dismiss the worth of minority groups. However, some networks transmit collective action frames that contest conventional social scripts and suggest political challenges are necessary, important, and worthwhile. While networks can cultivate the sort of attitudes that predispose people toward activism, they also draw people into specific political mobilizations. Political parties, committed partisans, and movement activists often try to motivate activism along through different persuasive techniques (e.g., face-to-face conversations, phone calls, email, direct mail, etc.). While each of these mediums transforms some sympathetic bystanders into activists, it is often argued that audiences are more responsive to recruitment pitches when they are encouraged or asked to be active by someone who they personally know (Hritzuk and Park 2000; Jasper and Poulsen 1995; Lim 2008). As such, social networks seem to play the dual purpose of pushing and pulling people into political activism. In effect, social networks boost political engagement since they often convey the attitudes that make people prone or receptive to activism and they also disseminate the logistical information that make activism possible (Duncan 1999; La Due Lake and Huckfeldt 1998; Lim 2008). 
In GLB activism studies, the concept of social network immersion works has been measured via network size, network density, and types of group affiliations (Elbaz 1996; Lombardi 1999; Waldner 2001). Some studies find that gays and lesbians who routinely talk with other gays and lesbians were more politically active (Lombardi 1999; Tester 2004). Other studies suggest that membership in specific voluntary groups matters even more. This is based on the premise that civic groups are activist hotbeds since they provide wider access to relevant information and have a higher concentration of friends who expect high levels of community engagement (Lim 2008). While joining a gay athletic club or a gay-friendly church may sensitize participants about shared grievances and enhance group solidarity, theorists have often argued that the gay and lesbian community centers are the strongest engines of cognitive liberation (Bernstein 1997). While GLB centers provide access to psychological and educational resources, they also introduce political rookies to explicitly political networks (e.g., consciousness-raising groups and national gay rights groups that block recruitment at their functions). In turn, this integration into GLB centers seems to translate into greater political activism (Elbaz 1996; Lombardi 1999; Waldner 2001). In fact, several multivariate studies have found that the best predictor of gay and lesbian activism was membership in GLB groups (Lombardi 1999; Waldner 2001).

In turning this previous literature into a testable theoretical model, this study examines how resource, framing, and mobilizing variables predict political participation among GLB respondents. By applying the nine variables of family income, education, sex, institutional legitimacy, internalized heterosexism, a bisexual identity, activist identities, perceptions of efficacy and group membership to our national sample, we identified factors that distinguished which gays and lesbians were more politically active. While researchers have tested similar models among heterosexual populations, this is not true among studies of gay and lesbian activists, as GLB studies rarely go beyond a handful of variables at a single time. In creating an integrated model, we hoped to assemble a more robust final model. We also hoped to eliminate or minimize the presence of spurious relationships that come from reductionistic theoretical models.

\section{Methods}

\section{Sampling}

To test the relevance of our predictor variables, we use 3 years of data from the General Social Survey (GSS). This biannual survey offers a random sample of American adults since 1977. Although GSS fails to directly ask questions about a respondent's self-identified sexual orientation, it is possible to identify the sex of the respondent and the sex of a respondent's sexual partners. One item asked individuals if they have exclusively had sexual intercourse with women, men, or both sexes in the last year. Accordingly, this study created a GLB subsample by selecting only the respondents who were males who only had sex with males (gay), females who only had sex with females (lesbians) and anybody who had sex with both males and females (bisexuals). Although GSS started asking this question in 1988, only 541 of the 29,093 respondents in the last 20 years fell under a GLB classification (see also Binson, et al. 1995; Lewis 2005).

The 1996, 2002, and 2004, GSS modules had questions that were germane to both political participation and our list of independent variables. While GSS is famous for its generalizability, it also offers some missing data problems. Since GSS rotates different sets of questions throughout a given year, the total data file has variables with long stretches of blank data. In response, this study only kept the respondents who had answered items for all of our selected measures. While this shrunk the sample size to 184 GLB citizens, it also avoids the problems of using shaky imputation techniques for missing data and having skewed results due to listwise regression techniques.

\section{Descriptions of the Sample}

The sample of 184 participants had a majority male and white composition (58\% male and $81 \%$ white). The mean of age of the sample was 39.8 years old with $27 \%$ of the respondent being under age $30,52 \%$ in the ages $30-50$, and $21 \%$ ages 51 and above. ${ }^{2}$ The sample included a diverse array of incomes. When using 1977 dollars as a constant, $21 \%$ of the sample had family incomes below $\$ 10,000$ per year, 57\% made $\$ 10,001-40,000$ per year, and 22\% made over $\$ 40,001$ per year. The sample was relatively highly educated, with $5 \%$ earning a middle-school diploma, $31 \%$ having earned a high school degree, 41\% having some college or a bachelor's degree, and 13\% having a professional or graduate degree. Participants were distributed throughout urban and rural locales, with $9 \%$ residing in metropolitan centers of over $1,000,0000$ people, $25 \%$ residing in cities of 999,999 to $100,000,40 \%$ residing in towns of 99,999 to 10,000 and $26 \%$ residing in smaller towns that had less than 10,000 .

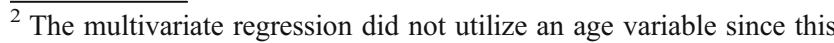
factor was not close to significant in preliminary Pearson $\mathrm{R}$ correlations.
} 
Political Participation Variables

In democratic societies, citizens engage in a range of conventional and unconventional political behaviors. The options of voting, volunteering for elections, making campaign contributions, and contacting elected officials are typically considered "electoral," "insider," or "institutionalized" methods of political participation. The techniques of boycotts, strikes, demonstrations, vigils, and civil disobedience are classified as "outsider" or "confrontational" tactics. While these and other options are varied in real life, there were only three items that were consistently asked for every year in this sample (1996, 2002, 2004). When creating three dependent variables, GSS respondents indicated whether they had or had not "donated money or raised funds for a social or political activity," "attended a political meeting" or "took part in a demonstration" during the last year or distant past. Answers for the single-itemdependent variables of donations, meetings and protesting were coded in a binary fashion (active if the respondent had done the action is the last year or distant past, nonactive if they have not done it and never will).

\section{Family Income}

Family income was measured by asking, "What was your family's income during the current year?" After converting the answers into 1977 real dollars, the responses were divided into four quartiles $(1=$ under $\$ 12,000 ; 2=\$ 12,001$ to $20,000,3=20,001$ to 40,000 and $4=$ over $\$ 40,000$ ).

\section{Educational Attainment}

Educational attainment was discerned through the highest degree attained and was measured on a 5 -point scale $(0=$ less than high school, 1=high school, 2=junior college, $3=$ baccalaureate, $4=$ graduate or professional).

\section{Sex}

Sex was measured through the item, "What is your sex?" $($ male $=1$, female $=0)$.

\section{Collective Action Frames}

GSS had three items that attend to framing concepts. To address internalized heterosexism, or the extent in which GLB respondents endorse the hegemonic premises that heterosexuality is the normal, natural, acceptable and superior version of sexuality, GSS stated: "Homosexuality is wrong" (always wrong, almost always wrong=1, other= $0)$. The dataset also contained an item on traditional gender roles. The relevant item proffers a traditionalist slant on parental gender roles: "It is better for men to work and women to tend home" (strongly agree, agree $=1$, other $=0$ ). While this variable has never been tested in studies of gay and lesbian activism, the acceptance of liberal gender precepts are often associated with the support of expanding more rights for gay and lesbian citizens (Crane et al. 2005; Haider-Markel and Joslyn 2008). Finally, the concept of authoritarian orientation was assessed through: "People should obey laws without exception" (always obey law $=1$, other $=0$ ).

\section{Political Efficacy}

Political efficacy was explored through one item on external power. The statement dealt with expectations of how similar people can influence governmental practices: "People like me do not have much of a say in what government does" (strongly disagree, disagree $=1$, other $=0$ ).

\section{Activist Identities}

Activist identities were discovered through an expected behavioral response to a governmental wrongdoing. More precisely, the item looked at a readiness to respond to the passage of unfair governmental statute: "How likely would you do something if an unjust law was being considered?" (very likely, somewhat likely $=1$, other $=0$ ).

\section{Number of Group Memberships}

Number of group memberships was measured as a composite score that reflected the number of voluntary and civic groups that a person joined. Respondents were given one point for every time that they indicated if they belonged to a union, a sports group, an art or literary club, or a religious group. Scores ranged from 0 (no groups) to 4 (all groups).

\section{Political Year}

The extent of citizen activism may fluctuate with cyclical nature of political processes. Be it through either "suddenly imposed grievances" that forces an immediate and urgent call toward political action (Jasper and Poulsen 1995; Walsh 1981), or the "expanding political opportunity structures" that signals vulnerabilities in political opponents (Meyer and Staggenborg 1996; Tarrow 1994), it is possible that the propensity toward political activism varied throughout the years of this study. To control for such issues, we created a correlation matrix for our three dependent variables and the yearly dummy variables of 1996, 2002, and 2004 (results not included in this paper). With 2004 being the only significant catalysts of activism, we added a 
dichotomous variable of $2004=1$ and other $=0$ to our multivariate analysis. This data confirms some early research that asserts activism among GLBs increased in the 13 states that held referendum votes on banning "samesex marriages" in 2004 (Riggle et al. 2009).

\section{Results}

\section{Descriptive Statistics}

Table 1 displays the amount of political activity among the respondents. Roughly $16 \%$ of the GLB sample gave money to a political group, $11 \%$ had been to a demonstration, rally, or vigil, and $6.5 \%$ attended a political meeting (column with people who reported same-sex sexual experiences). These patterns of GLB activism are somewhat similar to broad trends in the general population. Nevertheless, such tendencies slightly deviate from the political activities of heterosexuals in the GSS for the same 3 years (assuming that the respondents who said that their sexual intercourse was exclusively limited to opposite sex partners are heterosexuals). When addressing specific political actions, GLBs chose outsider tactics more often than heterosexuals. In the 3 years of the study, $11 \%$ of GLB respondents went to protests while only $6.4 \%$ of heterosexuals did the same thing. Conversely, heterosexuals employed insider tactics more frequently. Eighteen percent of heterosexuals gave donations to political causes and $12 \%$ of this category attended a political meeting. Two of these differences in political participation were statistically significant when using a one-way ANOVA (protesting actions $f=6.922$, $p<.01$; meeting attendance $f=5.223, p<.05$ ).

\section{Explanatory Statistics}

Given the binary nature of our dependent variables, we deemed a discriminant analysis the most appropriate multivariate technique (Aldrich and Cnudde 1975; Kleca

Table 1 Frequency of political participation by amount of same-sex sexual contact

\begin{tabular}{llll}
\hline Item & $\begin{array}{l}\text { Same-sex } \\
\text { sexual contact } \\
\text { Yes (\%) }\end{array}$ & $\begin{array}{l}\text { No same-sex } \\
\text { sexual contact } \\
\text { Yes (\%) }\end{array}$ & $F$ ratio \\
\hline $\begin{array}{l}\text { Gave money to a } \\
\text { political group }\end{array}$ & 15.8 & 18.0 & 0.794 \\
$\begin{array}{l}\text { Attend a meeting of a } \\
\text { political group }\end{array}$ & 6.5 & 12.1 & $5.223 *$ \\
$\begin{array}{l}\text { Go to a } \\
\text { demonstration, rally } \\
\text { or vigil }\end{array}$ & 11 & 6.4 & $6.922^{* *}$ \\
\hline$* p<05 ; * * p<01 ; * * * p<001$ & & \\
\hline
\end{tabular}

$* p<05 ; * * p<01 ; * * * p<001$
1980; Sherry 2006). Approaches like discriminant analysis proficiently highlight crucial independent variables that maximize the likelihood of a respondent belonging to a particular group (doing a political action or not). Or, otherwise stated, discriminant analysis excels at predicting group membership based on a linear combination of interval independent variables. Accordingly, three discriminant analyses were performed as all ten independent variables were entered into the formulas concurrently.

Discriminant analysis shares many qualities of more familiar general linear regression models. When exploring the importance of specific variables, the calculated standardized discriminant functions are analogous to $\beta$ weights in Ordinary Least Squares regressions (the language of discriminant analysis often calls independent variables "discriminators" and a dependent variable a "criterion"). As such, standardized discriminant functions convey the unique contribution of each independent variable after the contributions of other independent variables are controlled. Like $\beta$ weights, the relative strength of the predictors can be gleaned by comparing the size of the standardized discriminant functions (strength is determined by now far the coefficients move away from zero).

In the multivariate context, other similar functions are seen. By exploring the squared canonical correlations, researchers can also uncover the amount of total variance explained by all of the independent variable found in the regression (this effect size is akin to $R^{2}$ in Ordinary Least Square Regressions). A Wilkes' Lambda $(\lambda)$ provides the chi-squares $\left(\chi^{2}\right)$ that tests the significance for the entire function while the analysis also provides results on how well the full model accurately predicts membership in one of the two categories in the dependent variable (sometimes called a "hit ratio"). Although there is no universal "rule of thumb" regarding an acceptable rate of classifications, researchers assume that a $50 \%$ hit ratio is what would happen by chance alone and the higher number of correct classifications is preferred. The proper use of discriminant analysis carries many stipulations that were met by our research design. ${ }^{3}$

\footnotetext{
${ }^{3}$ Some of the major assumptions are: (1) the categories in the dependent variable are exhaustive and mutually exclusive; (2) the proportion of respondents in each group in the dependent variable exceeds $10 \%$; (3) there are less independent variables in the analysis than the number of respondents in each category in the dependent variables; (4), the independent variables are measured in interval levels; (5) there is low multicollinearity between the independents; (6) each group in the dependent variable must demonstrate a multivariate normal distribution on the independent variables; and the (7) covariance matrices for each group must be close to equal. Our research design and sample size dealt with the first four assumptions and the analysis of scatterplots for the Mahalanobis distances, coefficients of kurtosis, and Box's M results dealt with remaining assumptions.
} 
A discriminant analysis was run for the three dependent variables and every resource, network, and framing variable (see Table 2 for regressions and the appendix for the discriminant structure matrix). When exploring the predictive capabilities of the entire model, the Wilks' $\chi^{2}$ for each dependent variable easily reached significance $(p<001)$ and the effect sizes ranged between .316 and .253. With the total model explaining about $32 \%$ to $25 \%$ of the variance for each political activity, and the model correctly classifying group membership between $91.8 \%$ and $85.2 \%$ of the time, it is clear that the assembled predictors critically differentiated between GLBs who did and did not engage in outsider and insider politics.

Specific variables also made unique contributions. Two variables were significant across every political action. With standardized discriminant functions falling between .697 and .598 , it is clear that having an activist identity was the best predictor of different sorts of activism $(p<.001)$. The mobilizing factor of previous group memberships always netted significant results, but the strength of its association varied dramatically. Being a member of civic groups was strongly linked to attending political meetings (standardized coefficient $=.686, p<.001$ ), but its strength was much weaker for political donations and protest involvement (standardized coefficients ranged between .088 and $.070, p<.05$ ).

Most of the remaining variables saw their significance fluctuate with the different political behaviors. Four predictors achieved significance for making contributions and joining demonstrations but failed to do so for political meetings. Images of collective efficacy made a dramatic impact on joining collective protests (standardized coefficient $=.622, p<.001$ ) but impressions of group power were less crucial when giving money to political organizations (standardized coefficient $=.188, p<.01$ ). Educational attainment was statistically significant for two of the actions (although the coefficient slipped from .230 to .196, $p<.01$ and $p<.05$ ) as was the acceptance of heteronormative belief systems (coefficients of -.285 and $-.189, p<.01$ ). However, these variables showed inverse relationships as advancing through school generated more activism and embracing insidious depictions of homosexuality suppressed activism among GLB citizens. The election years of 2004 also increased donating and protesting tendencies (coefficients of .226 and .150, $p<.01$ ). Finally, two framing variables were significant for only one regression. While condoning conventional gender precepts often diminished political participation among respondents, these beliefs only significantly mattered for financial transfers (coefficient $=-.203, p<.01$ ). Also, the tendency to defer to authority figures mattered only for contesting the social order through protests and street actions (coefficient $=-.204, p<.05$ ).
One demographic factor reached significance only once. While men were more likely to engage in insider politics and women were more likely to partake in demonstrations, the sex variable only became significant for the donation variable (coefficient $=.196, p<.05$ ), as males were more likely than females to donate money to political causes. Finally, the variable of income never was able to reject the null.

\section{Discussion}

\section{Methodological Considerations}

Every data set offers strengths and weaknesses. This study offers the advantage of comparing the different qualities of activists and non-activists (earlier GLB activism studies have yet to do so). Additionally, the sample is national and random in scope (GLB activism studies have used local samples gathered through convenience or snowball techniques). While these strengths enhance the representativeness and external validity of the sample, our way of indirectly identifying GLB participants is far from ideal. That is, people in this sample may not call themselves gay or lesbian although they have had same-sex sexual experiences. Additionally, some could worry that the sample is too small or that we relied upon excessively restrictive definitions of sexual orientation, in that only the respondents who claimed to have sexual intercourse with a person of the same sex were included in the sample. This operationalization of sexual orientation does not account for a multitude of dimensions that could fall under a GLB identity (e.g., samesex attraction). Subsequently, the smaller sample size makes it harder to reject the null and these findings may not perfectly apply to self-identified GLBs who have not had sex with same-sex partners nor to people who have samesex partners but call themselves heterosexual. ${ }^{4}$

Another benefit of GSS is that it had enough suitable measures to test different theoretical models. Conversely, a suitable measure is not the same thing as a perfect measure. To the chagrin of the researchers, GSS had measures for only a few items on political actions for the 3 years in this study (1996, 2002, 2004). While going to a protest, giving money, or volunteering for a political group are clearly political endeavors, more exhaustive analysis would have included a wider list of insider and outsider tactics (e.g., voting, making campaign contributions, wearing political buttons, doing

\footnotetext{
${ }^{4}$ There many long debates on the reliability of using GSS to find a GLB sample. On one hand, Black et al. (2000) argue that GSS has numerous coding errors while Lewis (2005) and query. Binson et al. (1995) argue that GSS is the best national sample that does not focus on sexuality matters.
} 
Table 2 Standardized discriminant coefficients of involvement in different political activities for people with same-sex sexual contact $(N=184)$

\begin{tabular}{llll}
\hline Variable & Donation to a political activity & Attended a political meeting & Took part in a demonstration \\
\hline Income & .182 & -.144 & .048 \\
Educational attainment & $.196^{*}$ & .155 & $.230^{* *}$ \\
Sex (male=1) & $.198^{*}$ & .185 & -.146 \\
Internalized heterosexism & $-.189^{*}$ & -.004 & $-.285^{*}$ \\
Traditional gender roles & $-.203^{* * *}$ & -.044 & -.041 \\
Authoritarianism & -.063 & -.067 & $-.204^{*}$ \\
Perceived political efficacy & $.188^{* *}$ & .024 & $.622^{* * *}$ \\
Activist identity & $.697^{* * *}$ & $.598^{* * *}$ & $.601^{* * *}$ \\
Number of group memberships & $.070^{*}$ & $.686^{* * *}$ & $.088^{*}$ \\
Election year 2004 & $.150^{* *}$ & .010 & $.226^{*}$ \\
Wilks' $\lambda$ & .683 & .693 & .742 \\
$\chi^{2}$ test of Wilks & $66.63^{* * *}$ & $64.295^{* * *}$ & $52.11^{* * *}$ \\
Squared canonical correlation & .316 & .306 & .253 \\
Group centroids group 1 (yes) & 1.535 & 2.492 & 1.622 \\
Group 2 (no) & -.295 & -.176 & -.212 \\
Overall\% correctly classified & $91.8 \%$ & $91.8 \%$ & $85.2 \%$ \\
\hline
\end{tabular}

${ }^{*} p<05 ; * * p<01 ; * * * p<001$

collective kiss-ins, etc.). Additionally, our measures of political participation did not include the goals behind such actions. That is, we do not know the political causes connected to these actions. While much of our GLB respondent's political actions may be on behalf of gay and lesbian rights, the actions could have been connected to endless amount of different political grievances (e.g., workers or women's rights, health inequities, pro-life or anti-immigration campaigns). If these actions were undertaken as a means of prioritizing goals other than gay or lesbian rights, it might explain why the variable of internalized heterosexism and traditional gender roles were not significant in every regression (see the ensuing discussion for other reasons that might explain this lack of importance). This phenomenon would also demand the inclusion of different types of injustice frames in future computations. Similarly, when considering some of the predictor variables, the measurement of framing variables with a single item is not optimal. Future studies might want to include multidimensional scales on internalized heterosexism (Szymanski and Chung 2001), gender roles (Swim et al. 1995) and activist orientations (Corning and Meyers 2002). For example, some have argued that internalized heterosexism scales have more of ramifications when they include issues of shame and self-hatred or feelings of contempt for other GLB individuals (Currie et al. 2004; Mayfield 2001; Szymanski and Chung 2001).

Another shortcoming is connected to how often the data were collected. As with any cross-sectional study, problems of temporal ordering are always looming. Although efficacy and identities were associated with activism, we cannot be certain as to whether these frames actually preceded political activism, as it is possible that both of these frames were altered or cultivated during the process of being politically active. Likewise, respondents could have joined some civic groups after bouts of activism and doing activism can inspire people to enroll in college.

\section{Implications}

Even with these methodological caveats, we think our data provide some illuminating findings. First, gays and lesbians were more inclined to protest than their heterosexual counterparts (see Duncan 1999). This echoes a truism that disadvantaged group members often turn to outsider tactics faster than privileged groups, in part because political opportunity structures are less responsive to stigmatized groups (Tarrow 1994). Moreover, the use of social movements tactics seems wise since protest activities have been associated with the decriminalization of homosexuality (Frank and McEneaney 1999), removal of biased sodomy laws (Kane 2003) and the passage of state antidiscrimination laws (Haider-Markel and Meier 1996; Wald et al. 1996).

By examining the factors that inspire activism among gays and lesbians, this quantitative study tested the insights of "resource," "framing," and "mobilization" theories of political participation. In the end, each theory provided vital variables to this analysis. The resource model had some- 
what mixed results. The factor of educational attainment moved people to activism in two cases, while a person's sex only inspired activism once. While it appears as if education prompted greater political engagement, the exact mechanisms behind this relationship were far from clear. It could be that the resource theorists were correct in claiming that colleges foster the sort of analytical skills that are necessary for activism. Among other things, it is also possible that content of college curriculums inspires a new sense of civic responsibilities or that college settings often grant access to a wider scope of gay and lesbian social circles. The role of sex played a small role for only financial donations and nothing else. Men gave more money to political causes than women, but the "gender gap" was pretty indistinguishable for other political actions (interestingly, lesbians were slightly more prone to protesting behaviors).

In challenging resource theories, the variable of income was never consequential. The lack of significance for salary can mean two different things. Class backgrounds may in fact fail to predict activism among gays and lesbians. This interpretation could indirectly confirm "Post-Materialist" and "New Social Movement" theories that claim gay activists are more concerned with challenging cultural codes than with the unequal distribution of financial resources (Bailey 1999; Inglehart 1971; Johnston et al. 1994; Van Dyke et al. 2004). Alternatively, the proponents of the "resource" theories of participation could argue that our research methodologies probably underestimated the effects of family income. With the battles over what constitutes a gay and lesbian family, the measures of family income may be less reliable for GLB respondents, in that some respondents may have over or underestimated their family income level. Matters of wealth and salaries could have also displayed larger consequences if we excluded current college students from the sample (students have a truncated dispersion of salaries). No matter what the case may be, future researchers should be leery of assertions that income disparity is crucial driving force of activism among GLB populations.

Collection action frames also contributed some crucial variables. Activism was contingent upon the extent of some perceived grievances among GLB citizens. Respondents who chastised homosexuality and embraced conservative gender scripts were less likely to donate to a political cause and go to a demonstration. Additionally, people with authoritarian outlooks were also less likely to resort to outsider versions of street politics. Thus, conventional frames on the superiority of heterosexuality and the virtues of following authority figures were key determents to political engagement of sexual minorities. While embracing of orthodox family, gender, and sexuality precepts stilted activism among GLB respondents, it is possible that other injustice frames might be important as well. For example, it is possible that African-American or Latino/a respondents are driven by concerns over racism. Nevertheless, we assume that issues of sexual biases and heteronormativity are the most salient topic for the entire GLB population, and direct measures of experienced or perceived levels of homophobic discrimination would present even stronger associations (Duncan 1999; Hyers 2007; Jennings and Andersen 2003; Waldner 2001). Thus future research should incorporate measures of perceived or experienced discrimination into upcoming studies on gay and lesbian activism (Morrison and Morrison 2002; Walls 2008).

While injustice frames were relevant to political participation, the perceived righteousness of prevailing institutions was not the main framing factor. With activist identities offering the highest coefficients, it is clear that activists felt obliged to act against unjust laws. This implies that activism is grounded in moral commitments to social justice and the normalizing identities that make one willing to challenge societal mores. Again, this confirms the veracity of "New Social Movement" theories which see collective identities as the major force behind gay and lesbian activism (Bernstein 1997; Taylor and Whittier 1992). However, this commitment to fighting against unjust laws might not be seen as purely altruistic since two types of activism increased when anti-gay initiatives were placed on state ballots (2004).

With perceived collective efficacy being significant in most cases, it is clear that activists, when compared to nonactivists, displayed much greater faith in both their personal and collective capacities to create social change. This may also mean that GLBs are less likely to join political efforts when they think the government is unresponsive to their demands and when they doubt their personal capabilities. This suggests that collective identities must also include "success expectancies" when motivating gays and lesbians into political activism.

This study also reveals the importance of mobilizing structures and social networks. Gays and lesbians who were active in unions, artistic associations, sporting clubs, and religious groups were more politically active. While this confirms the claims of mobilization theories, it also opens new questions. It would be interesting to discover if this variable would gain potency when membership in gay and lesbian groups is merged into the scale. Moreover, it would be interesting to discover 
why some of the less explicitly political groups inspired greater activism. Finally, future researchers should explore the mechanisms behind this association. Do civic groups simply offer greater access to political discussions or do they offer more specific information about upcoming political events? Or, do the conversations in these groups build the sort of identities that compel GLBs into activism? Perhaps those who participate in community groups simply enjoy and are drawn toward communal action, social bonding, and organized activities.

Finally, this study suggests that political participation is connected to temporal matters. Whether joining together in their dislike of the governing Republican Party, having collective outrage about the anti-gay marriage amendments of 2004, or responding to the extra efforts of fairness alliances to mobilize their constituents, 2004 saw a noticeable increase in political activism among gay and lesbian respondents in this study. Thus, future researchers might want to use aggregated data to determine why greater activism in 2004 occurred. This research should be illuminating since early studies have offered conflicting results on whether the state bans on same-sex marriage spurned greater activism among heterosexuals (i.e., Abramowitz and Stone 2006; Campbell and Monson 2008; Lewis 2005; Riggle et al. 2009; Sitka and Bauman, 2008).

While our study tested numerous variables, the entire list is not totally exhaustive. Future studies might want to add new variables into the mix. Scholars might see if the demographic variables of race, age, or residential mobility influences political participation (Harder and
Krosnick 2008). Other studies might explore the role of other framing process. Publicly embracing a gay or lesbian sexual identity might lead to greater activism. It also is possible that general impressions of discrimination, attributions of system for such discrimination, perceived importance and certainty of their sexual orientation, favorable impressions of other gays and lesbians, a sense of interdependence and mutual fate among gays and lesbians, a dislike for heterosexuals, or perceptions of civic duties can also incite further activism (see Miller et al. 1981; Ashmore et al. 2004). The impact of different mobilizing structures could be illuminating in this regard. Befriending straight activists, living in liberal neighborhoods, or going to "gay-friendly" colleges could foster greater activism. Conversely, living in isolated rural communities or being raised in socially conservative families could dampen any inclinations to GLB activism. Other studies may also explore the question as to whether a person has ever had contact with someone who has asked them to join a political movement. Overall, this study shows the potency of eclectic theoretical models that synthesize variables from the resource, collective action framing, and network perspectives. Moreover, despite the intensity of heteronormativity experienced by members of the gay and lesbian communities in this country, GLB populations have found a variety of ways to make their voices heard and participate in both insider and outsider forms of collective action.

\section{Appendix}

Table 3 Correlations between independent variables

\begin{tabular}{|c|c|c|c|c|c|c|c|c|c|c|}
\hline Variable & 1 & 2 & 3 & 4 & 5 & 6 & 7 & 8 & 9 & 10 \\
\hline 1. Income & - & $.248^{* *}$ & .068 & -.111 & .054 & -.068 & .012 & -.017 & $.211^{* *}$ & .007 \\
\hline 2. Educational Attainment & & - & -.107 & $-.202 * *$ & $-.168^{*}$ & $-.123 *$ & $.162 *$ & $.185^{*}$ & $.190^{*}$ & .113 \\
\hline 3. Gender $($ Male $=1)$ & & & - & .026 & .013 & .051 & -.034 & -.089 & -.060 & .143 \\
\hline 4. Internalized Heterosexism & & & & - & $.236^{* *}$ & .012 & -.027 & -.062 & .108 & $-.161 *$ \\
\hline 5. Traditional Gender Roles & & & & & - & .086 & -.105 & -.144 & .005 & $-.162 *$ \\
\hline 6. Authoritarianism & & & & & & - & $.237 * *$ & -.089 & -.067 & $-.159^{*}$ \\
\hline 7. Perceived political efficacy & & & & & & & - & $.270^{* *}$ & $.162 *$ & .104 \\
\hline 8. Activist identity & & & & & & & & - & $.257 * *$ & $.453 * * *$ \\
\hline 9 .Number of group memberships & & & & & & & & & - & .024 \\
\hline 10. Election Year 2004 & & & & & & & & & & - \\
\hline
\end{tabular}




\section{References}

Abramowitz, A., \& Stone, W. (2006). The Bush effect: Polarization, turnout, and activism in the 2004 presidential election. Presidential Studies Quarterly, 36, 141-154.

Aldrich, J., \& Cnudde, C. F. (1975). Probing the bounds of conventional wisdom: A comparison of regression, probit, and discriminant analysis. American Journal of Political Science, 19, 571-608.

Arneson, B., \& Eells, W. (1950). Voting behavior in 1948 as compared with 1924 in a typical Ohio community. American Political Science Review, 44, 432-434.

Ashmore, R., Deaux, K., \& McLaughlin-Volpe, T. (2004). An organizing framework for collective identity. Psychological Bulletin, 130, 80-114.

Bailey, R. W. (1999). Gay politics, urban politics: Identity and economics in the urban setting. New York: Columbia University Press.

Barrett, D., \& Pollack, L. (2005). Whose gay community? Social class, sexual self-expression, and gay community involvement. The Sociological Quarterly, 46, 437-456.

Bernstein, M. (1997). Celebration and suppression: The strategic use of identity by the lesbian and gay movement. The American Journal of Sociology, 103, 531-565.

Binson, D., Michaels, S., Stall, R., Coates, T., Gagnon, J. H., \& Catania, J. (1995). Prevalence and social distribution of men who have sex with men. Journal of Sex Research, 32, 245-254.

Black, D., Gates, G., Sanders, S., \& Taylor, L. (2000). Demographics of the gay and lesbian population in the United States. Demography, 37, 139-154.

Brady, H., Verba, S., \& Scholzman, K. (1995). Beyond SES: A resource model of political participation. The American Political Science Review, 89, 271-294.

Campbell, D., \& Monson, J. Q. (2008). The religion card: Gay marriage and the 2004 presidential election. Public Opinion Quarterly, 72, 399-419.

Cole, E., Zucker, A., \& Ostrove, J. (1998). Political participation and feminist consciousness among woman activists of the 1960's. Political Psychology, 19, 349-371.

Corning, A., \& Meyers, D. J. (2002). Individual orientation toward engagement in social action. Political Psychology, 23, 703-729.

Crane, S., Martinez, M., Kane, J., \& Gainous, J. (2005). Core values, value conflict, and citizens' ambivalence about gay rights. Political Research Quarterly, 58, 5-17.

Currie, M., Cunningham, E., \& Findlay, B. (2004). The short internalized homonegativity scale. Educational and Psychological Measurement, 64, 1053-1067.

Duncan, L. (1999). Motivation for collective action: Group consciousness as mediator of personality, life experiences and women's rights activism. Political Psychology, 20, 611-635.

Edwards, L., \& Romero, A. (2008). Coping with discrimination among Mexican descent adolescents. Hispanic Journal of Behavioral Sciences, 30, 24-39.

Elbaz, G. (1996). Measuring AIDS activism. Humanity and Society, 20, 44-60.

Evans, N., \& Herriott, T. (2004). Freshman impressions: How investigating the campus climate for LGBT students affected four freshmen students. Journal of College Student Development, $45,316-332$.

Frank, D. J., \& McEneaney, E. H. (1999). The individualization of society and the liberalization of state policies on same-sex sexual relations. Social Forces, 77, 911-943.

Friedman, C., \& Leaper, C. (2010). Sexual-minority women's experiences with discrimination: Relations with identity and collective action. Psychology of Women Quarterly, 34, 152-164.
Gamson, W. (1992). The social psychology of collective action. In A. D. Morris \& C. Mueller (Eds.), Frontiers of social movement theory (pp. 53-76). New Haven CT: Yale University Press.

Gitlin, T. (1980). The whole world is watching: Mass media in the making and unmaking of the new left. Berkeley, CA: University of California Press.

Gortmaker, V., \& Brown, R. (2006). Out of the closet: Differences in perceptions and experiences among out lesbian and gay students. College Student Journal, 40, 606-619.

Haider-Markel, \& Meier, K. J. (1996). The politics of gay and lesbian rights: Expanding the scope of the conflict. The Journal of Politics, 58, 332-349.

Hartman, J. (2005). Another kind of 'chilly climate': The effects of lesbian separatism on bisexual women's identity and community. Journal of Bisexuality, 5, 61-76.

Herek, G. (1992). The social context of hate crimes. In G. Herek \& K. Berrill (Eds.), Hate crimes (pp. 89-104). Newbury Park, CA: Sage.

Haider-Markel, D., \& Joslyn, M. (2008). Beliefs about the origins of homosexuality and support for gay rights. Public Opinion Quarterly, 72, 291-310.

Harder, J., \& Krosnick, J. (2008). Why do people vote? A psychological analysis of voter turnout. Journal of Social Issues, 64, 525-549.

Hritzuk, N., \& Park, D. (2000). The question of Latino participation: From an SES to social structural explanation. Social Science Quarterly, 81, 152-177.

Huddy, L., \& Khatib, N. (2007). American patriotism, national identity, and political involvement. American Journal of Political Science, 51, 63-77.

Inglehart, R. (1971). The silent revolution in post-industrial societies. American Political Science Review, 65, 991-1017.

Hyers, L. (2007). Resisting prejudice every day: Exploring women's assertive responses to anti-black racism, anti-Semitism, heterosexism and sexism. Sex Roles, 56, 1-12.

Jasper, J. M., \& Poulsen, J. D. (1995). Recruiting strangers and friends: Moral shocks and social networks in animal rights and anti-nuclear protests. Social Problems, 42, 493-512.

Jennings, M. K., \& Andersen, E. A. (2003). The importance of social and political context: The case of AIDS activism. Political Behavior, 25, 177-199.

Johnston, H., Larana, E., \& Gusfield, J. (1994). Identities, grievance and new social movements. In E. Larana, H. Johnston, \& J. Gusfield (Eds.), New social movements (pp. 3-35). Philadelphia: Temple University Press.

Jones, T. (2002). Characteristics of a group of lesbian and gay radical street activists. Journal of Gay and Lesbian Social Services, 14, $39-53$.

Kane, M. D. (2003). Social movement policy success: Decriminalizing state sodomy laws. Mobilization, 8, 313-334.

Klandermans, B. (1996). The social psychology of protest. New York: Blackwell.

Klecka, W. R. (1980). Discriminant analysis. Thousand Oaks, CA: Sage.

Konik, J., \& Stewart, A. J. (2004). Sexual identity development in the context of compulsory heterosexuality. Journal of Personality, $72,815-844$.

La Due Lake, R., \& Huckfeldt, R. (1998). Social capital, social networks and political participation. Political Psychology, 19, $567-584$.

Leighley, J., \& Nagler, J. (1992). Individual and systemic influences on turnout: Who votes? Journal of Politics, 54, 718-740.

Leighley, J., \& Vedlitz, A. (1999). Race, ethnicity and political participation. Journal of Politics, 61, 1092-1114.

Lewis, G. (2005). Same-sex marriage and the 2004 presidential election. PS, Political Science \& Politics, 38, 195-200. 
Lien, P. (1993). Ethnicity and political participation: A comparison between Asian and Mexican Americans. Political Behavior, 16, 237-264.

Lim, C. (2008). Social networks and political participation: How do networks matter? Social Forces, 87, 961-982.

Lombardi, E. (1999). Integration within a transgendered social network and its effect upon members' social and political activity. Journal of Homosexuality, 37, 109-122.

Mayfield, W. (2001). The development of an internalized homonegativity inventory for gay men. Journal of Homosexuality, 41, 5376.

McAdam, D., \& Paulsen, R. (1993). Specifying the relationship between social ties and activism. The American Journal of Sociology, 99, 640-667.

McCarthy, J. D. (1996). Mobilizing structures: constraints and opportunities in adopting, adapting and inventing. In D. McAdam, J. D. McCarthy, \& M. N. Zald (Eds.), Comparative perspectives on social movements (pp. 141-151). Boston: Cambridge University Press.

Miller, A., Gurin, P., Gurin, G., \& Malanchuk, O. (1981). Group consciousness and political participation. American Journal of Political Science, 25, 494-511.

Morrison, M., \& Morrison, T. (2002). Development and validation of a scale measuring modern prejudice toward gay men and lesbian women. Journal of Homosexuality, 43, 15-37.

Meyer, D., \& Staggenborg, S. (1996). Movements, countermovements, and the structure of political opportunity. The American Journal of Sociology, 101, 1628-1660.

Passy, F. (2001). Socialization, connection, and the structure/agency gap: A specification of the impact of networks on participation in social movements. Mobilization, 6, 173-192.

Polletta, F., \& Jasper, J. (2001). Collective identity and social movements. Annual Review of Sociology, 27, 283-305.

Riggle, E. D., Rostosky, S. S., \& Horne, S. G. (2009). Marriage amendments and lesbian, gay, and bisexual individuals in the 2006 election. Sexuality Research and Social Policy, 6, 80-89.

Rimmerman, C. (2007). The lesbian and gay movements: Assimilation or liberation? Boulder, CO: Westview.

Rollins, J., \& Hirsch, H. N. (2003). Sexual identities and political engagements. Social Politics, 10, 290-312.

Sherry, A. (2006). Discriminant analysis in counseling psychology research. The Counseling Psychologist, 34, 661-683.

Simon, B., Lowry, M., Sturmer, S., Weber, U., Freytag, P., Habig, C., et al. (1998). Collective identification and social movement participation. Journal of Personality and Social Psychology, 74, 646-658.

Sitka, L., \& Bauman, C. (2008). Moral conviction and political engagement. Political Psychology, 29, 29-54

Sturmer, S., \& Simon, B. (2004). The role of collective identification in social movement participation: A panel study in context of the
German gay movement. Personality and Social Psychology Bulletin, 30, 263-277.

Snow, D., \& Benford, R. (1992). Master frames and cycles of protest. In A. Morris \& C. Mueller (Eds.), Frontiers in social movement theory (pp. 133-155). New Haven, CT: Yale University Press.

Stokes, A. K. (2003). Latino group consciousness and political participation. American Politics Research, 31, 361-378.

Swim, J., Aikin, K., Hall, W., \& Hunter, B. (1995). Sexism and racism: Old-fashioned and modern prejudices. Journal of Personality and Social Psychology, 68, 199-214.

Swim, J., \& Thomas, M. (2006). Responding to everyday discrimination: a synthesis of research on goal-directed, self-regulatory coping behaviors. In S. Levin \& C. van Laar (Eds.), Stigma and group inequality: Social psychological perspectives (pp. 105126). Mahway, NJ: Erlbaum.

Szymanski, D., \& Chung, Y. B. (2001). The lesbian internalized homophobia scale. Journal of Homosexuality, 41, 37-52.

Tarrow, S. (1994). Power in movement. New York: Cambridge University Press.

Tate, K. (1991). Black political participation in the 1984 and 1988 presidential elections. American Political Science Review, 85, $1159-1176$.

Taylor, V., \& Whittier, N. (1992). Collective identity in social movement communities: lesbian feminist mobilization. In A. Morris \& C. Mueller (Eds.), Frontiers in social movement theory (pp. 104-129). New Haven, CT: Yale University Press.

Taylor, V., Kimport, K., Van Dyke, N., \& Andersen, E. A. (2009). Culture and mobilization: Tactical repertoires, same-sex weddings, and the impact on gay activism. American Sociological Review, 74, 865-890.

Tester, G. (2004). Resources, identity and the role of threat: The case of AIDS mobilization. Research in Political Sociology, 13, 47-75.

Thompson, V. (2006). Coping responses and the experience of discrimination. Journal of Applied Social Psychology, 36, $1198-1214$.

Van Dyke, N., Soule, S., \& Verta, T. (2004). The targets of social movements: Beyond a focus on the state. Research in Social Movements, Conflicts, and Change, 25, 27-51.

Wald, K. D., Button, J. W., \& Rienzo, B. A. (1996). The politics of gay rights in American communities: Explaining antidiscrimination ordinances and policies. American Journal of Political Science, 40, 1152-1178.

Waldner, L. (2001). Lesbian and gay political activism: An analysis of variables predicting political participation. Research in Political Sociology, 9, 59-81.

Walls, N. E. (2008). Toward a multidimensional understanding of heterosexism. Journal of Homosexuality, 55, 20-70.

Walsh, E. (1981). Resource mobilization and citizen protest in communities around Three Mile Island. Social Problems, 29, $1-21$. 